\title{
The Impact of Foreign Investor Trading Activity on Vietnamese Stock Market
}

\author{
Tri Minh Nguyen ${ }^{1}$ \\ ${ }^{1}$ School of Development Economic, University of Economic, Ho Chi Minh City, Vietnam \\ Correspondence: Tri Minh Nguyen, School of Development Economic, University of Economic, Ho Chi Minh \\ City, Vietnam. E-mail: tri.nm@vnp.edu.vn
}

Received: December 27, 2016

Accepted: January 12, 2017 Online Published: January 16, 2017

doi:10.5539/ijms.v9n1p109

URL: http://dx.doi.org/10.5539/ijms.v9n1p109

\begin{abstract}
The empirical research examines the impact of net purchase of foreign investors on performance of stock market and market liquidity. In this study, market performance is proxied by $\mathrm{VN}$-index, which measures growth of equity market and market liquidity is estimated by the trading volume of whole market. The data is collected in Vietnamese Stock Exchange in the period of 1215 intraday from 2011 to 2014. By using ARCH model, main findings of this research are: first, there is positive relationship between market performance and net purchase; second, performance of stock market is influence by lag factor and third, liquidity of market is affected negatively by trading activity of foreign investors.
\end{abstract}

Keywords: foreign investors, trading activity, Vietnam, stock market

\section{Introduction}

It is undeniable that stock market is one of the most important components, which contributes to economic growth for some reasons. First, stock market is efficient channel where enterprises raise capital. Second, this provides high return investment environment for individual and corporate investors when they have free cash flow. Finally, stock market is the tool for State Bank or government to implement policy. In Vietnam, the stock market has generated basing on Degree No. 48/CP and Decision No. 127/1998/QD-TTG, which has been approved by Prime Minister on 10 Jul 1998. On 20 Jul 2000, the Ho Chi Minh City Securities Trading Center has officially opened with first trading transaction. Up to now, Vietnamese stock market has operated more than 15 years with two main centers: Ho Chi Minh Stock Exchange (HOSE) and Hanoi Stock Exchanged (HNX). Total number of listed companies is 694 and market capitalization was 985,258 billion VND on 2014. The graph bellow indicates the development of Vietnamese stock market through two main indexes: VN-INDEX and market capitalization. As can be seen, market capitalization has experienced a significant increase during ten years, except years 2008 and 2010 when there was in a crisis. Regarding to VN-INDEX, stock market in Vietnam became bubble in 2006 and 2007, which causes sharp rise in this figure. After the bubble broke, the market dropped down abruptly.

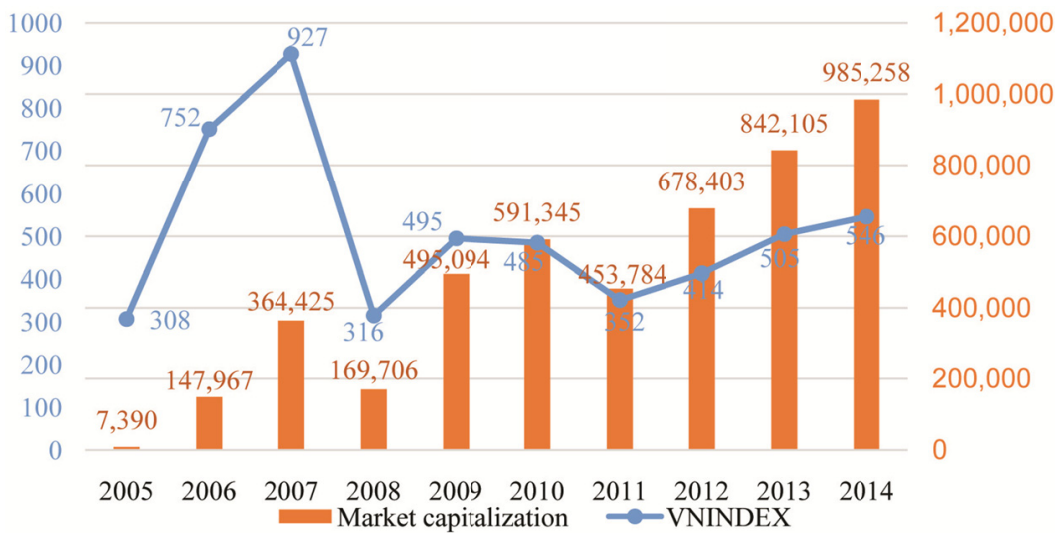

Graph 1. Market capitalization on last trading session of a year (Unit: billion VND) and VN-Index

Source: data from Ho Chi Minh Stock Exchange. 
For scale, the size of Vietnamese stock market is significantly smaller than other markets in Asian. The graph 2 indicates the percentage of market capitalization over Gross Domestic Products (GDP) in 6 countries: Vietnam, Thailand, Singapore, Indonesia, Malaysia and Philippine. Overall, Vietnam is nation having the lowest proportion of market capitalization and Singapore has the biggest one.

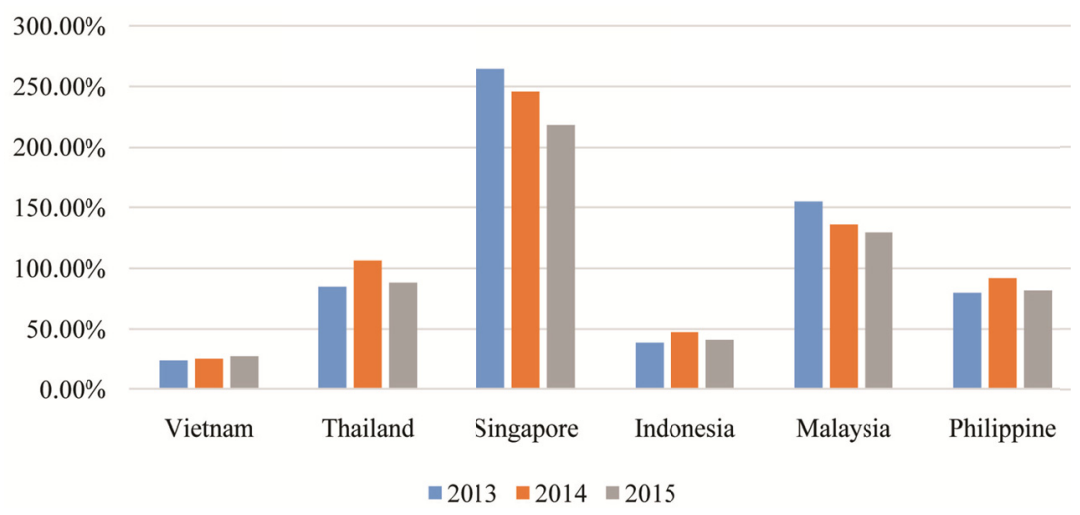

Graph 2. Market capitalization of listed domestic companies (\% of GDP)

Source: World bank's website.

Financial liberalization plays an important role on economic growth, especially for developing countries. However, the impact of this phenomenon is significantly different across countries and surveyed period time. Edison et al. (2004) review and summarize many papers related to relationship between capital account openness and economic performance. Quinn (1997) gives strong evidences to prove the strong influence of financial liberalization to GDP per capital in 58 countries from 1960 to 1989. Klein \& Olivei (1999) also indicate that openness of finance leads positive effect to industrial countries only and does not support to nonindustrial countries. Similarly, Edison et al. (2004) find out stock market liberalization associates positively to economic growth for middle-income countries, not for low-income and high-income countries. By contrast, there are several studies, which do not support this view. Rodrik (1998) takes the study on 100 countries in the period of 1975 and 1989 and finds no relationship between capital account liberalization and real income per capita. With same conclusion, Kraay (1998) uses variety estimation of financial liberalization also fails to confirm its significant effect on economic growth.

Edison et al. (2002) find out that international financial integration has positive impact on stock market development. Kim \& Singal (2000) prove that the stock market becomes more efficient when it is opened. Henry (2000) also confirms that stock market liberalization associates positively to economic growth for the sample of 11 developing market. Moreover, cost of capital will reduce when stock market has opened to foreign investors. In term of liquidity, Wang (2006) investigates Thailand stock market and gives the conclusion that stock market liquidity has positive relationship with transaction of foreign investors during crisis period. In term of risk, Bekaert \& Harvey (1997) confirm that liberalization of capital market reduces volatility for emerging market as well as increase the relationship between domestic market return and world market. Another study of Bekaert, Harvey, \& Lundblad (2002) present the role of liberalization of capital market to economy of emerging market. This research challenge the view that opening market influences positively functioning of stock market, capital structure, investment inflow, price levels and risk diversification of Vietnamese market. Mitton (2006) takes the research on a large sample of firms in 28 countries and gives the conclusion that the firms witness the growing period with higher profitability, higher investment and greater efficiency and lower financial leverage after opening equity market to foreigners.

Purpose of this study is doing research on the impact of foreign investors' purchase on stock market performance and liquidity in trading session in Vietnam stock market because up to now, nearly no empirical research studies about the impact of foreign investors on stock market. The data is collected in the period time of 01, Jan 2011 and 24, Nov 2015. Autocorrelation Conditional Heteroskedasticity model (ARCH) for time series data is used for this paper to examine the impact of net purchase's foreign investors on $\mathrm{VN}$-index and trading volume. The results show that there is a positive association between net purchase of foreign sector and stock market performance. By contrast, trading activity of foreign investor causes negative effect on liquidity.

The structure of this research is as follows. Section I reviews theoretical and empirical studies related to this 
topic. Section II presents data and descriptive findings. Methodology, model and variables are described in section III. Section IV shows the empirical results and interprets some problems as well as compared them with previous studies. Finally, section V summarizes the main findings and conclusions.

\section{Literature Review}

\subsection{Financial Liberalization and Stock Market Development}

Financial liberalization plays an important role on developing equity market in emerging countries. Henry (2000) conducts the research on the sample of 12 emerging markets and gives and strong evidence to prove that equity index witnesses the significant abnormal return after government opens capital market. By using some control variables like world stock return, macroeconomic factors and concurrent economic reforms, this paper suggests that cost of capital will be reduced by sharing risks between foreign and domestic investors. This is one big advantage that stock market liberalization brings to emerging countries. In these markets, asymmetric information as well as investment experience is always prevalent problem for individual investors. That is a reason why foreign sector plays an important role on leading the movement of market. With the same conclusion, Bekaert \& Harvey (2000) confirm that capital market integration reduces cost of capital as well as increases economic growth. Moreover, the reason for foreign investors to be attracted by emerging markets is to seek diversification for their portfolio. Stulz (1999) gives two channels to reduce cost of capital. First, financial liberalization decreases discount rate and second, expected cash flow increases due to increase in monitoring of management and shareholders. However, this study also points out that the significant reduction in cost premium is very small because of home bias effect. Choosing which country and which company to invest is complicated procedure and it depends on many factors. Aggarwal, Klapper \& Wysocky (2005) reveal that professional foreign investors tend to select the firms basing on not only their financial performance but also transparency and disclosure. The study of Levine \& Zervos (1998) indicates that stock market becomes bigger with higher liquidity after government implements international integration policy in finance. The regulatory indicators become better and equity market becomes more efficient and informational. The easy access to information by domestic and foreign companies associates positively to stock market development. Kassimatis (2002) conducts the research in six countries: Argentina, India, Pakistan, Philippines, South Korea and Taiwan, which confirms that openness of financial market reduces its volatility. Several recent empirical researches also present the positive relationship between financial integration and equity market development. Cajueiro, Gogas, \& Tabak (2009) reveal that Greek stock exchange receives many benefits from this phenomenon such as reducing cost of capital, improving market efficiency and economic environment.

By contrast, some studies show opposite view about impact of financial liberalization on equity market. Kawakatsu \& Morey (1999) illustrate that there is no significant difference in stock market before and after actual liberalization. Umutlu, Akdeniz, \& Altay-Salih (2010) show strong evidence to prove that there is negative influence on performance of small and medium markets as well as reducing stock returns. The mechanism of this impact is through aggregated idiosyncratic and local volatility. However, financial liberalization leads positive effect on foreign investor's returns through improving accuracy of public information. Bley \& Saad (2011) find no relationship between foreign ownership limit and idiosyncratic volatility but a rising impact in total volatility. Kaminsky \& Schmukler (2003) confirm that finance openness has negative effect in the short run but has positive effect in the long run on stock market. As their explanation, there is no preparation in government reforms before liberalization. Most of time, policies are implemented within few years after partially opening economy. As a result, the country cannot receive any benefit immediately due to lack of correct incentives.

\subsection{Foreign Trading Activities, Stock Market Returns and Performance}

Ciner \& Karagozoglu (2007) investigate impact of foreign trading activity on speculation of private investors. Their main finding is that return of individual speculators is influenced positively by foreign traders. With intellectual experience, foreign investors provide superior information, reduce asymmetric problem and cause the impact on whole market movements. Regarding capital flow, Thailand market witnesses same correlation between net purchase and stock fluctuation, which improves market liquidity since financial crisis happened. Wang (2007) also gives two economic interpretations for relationship between foreign investment and market volatility. Firstly, in emerging market, the purchase of foreigners enhances efficiency of market information and decreases volatility. This is investor base- broadening effect which is identified by Merton (1987). By this way, when widening investor base, risk is shared and required rate of return is reduced. Consequently, market volatility will be decreased. Secondly, this is implication of well-known leverage effect theory. It is defined that selling of foreign investors affects negatively to returns and causes greater fluctuation on stock price than their purchases. Similarly, Dahlquist \& Robertsson (2004) also point out that the permanent stock price was associated positively by net 
purchase of foreign investors. The explanation is that larger ownership of foreign shareholder reduces capital cost of firm and they have tendency to invest to the stocks which are better informed than others. The authors also confirm that in financial liberalization, risk sharing leads to the variety of cost of capital in many firms. Griffin, Nardari \& Stulz (2003) present the simple model of equilibrium equity flows to examine the impact of foreign investors to return of domestic ones as well as market performance. By using a bivariate structural VAR, this study gives strong evidence to prove that the foreign investors follow positive market performance. In U.S market, foreign cash inflow increases equity market's performance.

In contrast, for the impact of foreign investors on market liquidity, Rhee \& Wang (2009) confirm there is negative correlation between future market liquidity and foreign ownership in Indonesia. The special feature of this market is that foreign institution accounts for large percentage of share of listed companies and their share occupies about $41 \%$ of market capitalization in the period time 2002-2007. This paper also mentions the potential mechanism of this problem is asymmetric information. Similarly, Samal (1997) presents different conclusion about the role of foreign investors on emerging market. He conducts the research in Indian market from 1991 to 1996 after opening financial market. This study finds strong evidences to prove that foreign investment cash flow causes negative effect to equity market through manipulating price. The price of companies having good performance usually falls down and small domestic investors could be retreated. Wang (2007) uses market volatility as dependent variable and regresses on lagged volatility with some types of transactions: volume, value and number of trades. He collects data from stock market in two markets: Jakarta Stock Exchange (JSX) and Stock Exchange of Thailand (SET) and compares differences in impact of foreign investors on them. This study give strong evidences to prove the positive relationship between market volatility and foreign trading although the trading value of foreign investors accounts for just $15 \%$ and $18 \%$ of daily trading value in Indonesian and Thailand stock markets respectively. Moreover, sales between domestic investors and foreign investor associate negatively with market volatility. With the same result, Hamao \& Mei (2001) examine three viewpoints of restricting foreign investment. They mention that foreign investors only focus on short-term profits rather than long-term profits, which causes the loss for domestic investors and increases market volatility. The authors use three-stage least square to regress database of Tokyo stock market. Consequently, research confirms that market liquidity is enhanced by foreign investors and there is little dividend to prove that foreign investment leads the loss of local participants as well as increase volatility of Japanese equity market. Mukherjee, Bose, \& Coondoo (2002) investigate Indian market from Jan, 1999 to May, 2002 to examine the relationship between foreign institutional investment flows and equity market. By using regression for time series data of daily trading, this paper points out some interesting results. First, the return of Indian market attracts capital flow of foreign investors. Second, performance of equity market associates considerably revenue and net inflow of foreign institutions but their purchase does not effect on this market performance and third, there is auto-correlation among daily transaction

Chan, Menkveld, \& Yang (2007) investigate the relationship between two market segments: for domestic investors and foreign investors in China. They quoted A-share market for the formers and B-share market for the latters. This paper also examined the impact of fiscal policy of Chinese government, which allows domestic investors to trade A-share from 19 Feb 2001. By using Vector Autoregressive Model (VAR) and Vector Error Correction Model (VECM), this research points out the trading volume causes considerable influence to stock returns not only in same trading session but also in future stock returns. In more details,before 19 Feb 2001, A-share return and B-share return are able to be predicted strongly by A-share volume, while B-share volume has a little impact on A-share return. Then, after 19 Feb 2001, B-share affects significantly A-share in term of volume and quote revision. As explanation, the authors strongly believe that the domestic investors' trading contains more information than it of foreign investors. Because the number of trading activity in B-share market is lower than that in A-share market so much, the effect of B-share market on whole market is weaker. However, it does not mean foreign investors would receive more disadvantages than domestic others and return depends on strategy investment. With the same method, Bae et al. (2012) presentthe opposite result. They prove that in emerging market, the foreign traders are better informed and returns of local investors can be predicted by it of foreigners. It means that the domestic traders usually react basing on transactions of foreign investors, which facilitate information more efficiently. The participation of foreign sector to emerging markets increases adjustment in stock price. Richards (2005) also conducts the research in six Asian emerging markets about net purchase of foreign investors. This paper provides the strong evidence to prove that foreigners respond quickly to price change. Moreover, trading activity of foreign sector influences strongly to price and obviously, it leads to the increase in whole market. Especially, this effect is larger in emerging market than developed market

Choe, Kho, \& Stulz (1999) conduct the research about influence of foreign traders on stock return. They conducted intraday data on stock market of Korea from 30th November 1996 to the end of 1997. This study showed that 
before economic crisis, feedback trading and herd are positively engaged by foreign investors. However, during crisis, this signal is weak. In addition, the research had no evidence to prove that foreign sector destabilized Korea's stock market. The other research of Choe, Kho, \& Stulz (2005) present the trading of foreign investors in Korea and tested three hypothesis: (1) Foreign investors are less patient when trading on low liquidity market; (2) Foreign investors receive more information than domestic ones and (3) they trade stocks after price had moved against them. They use methodology of Pool Ordinary Least Square to examine the relationship between intensive trading volume of foreign investors and behavior of domestic investors as well as price movement. Some control variables related to firm and stock characteristics are added in the model. Database is conducted before, during and after trading period. Consequently, the main findings of this research are very various. Firstly, there is no evidence to prove that the domestic investors are worse informed. Secondly, greater impatience does not appear in foreign investor trade rather than domestic investors. Thirdly, foreign investors have tendency to trade intensively after stock price had moved more against their trading. It means that transaction of foreign sector directs movement of stock market.

\section{Data and Variables}

\subsection{Data}

In Vietnamese market, there are two stock exchanges: Ho Chi Minh stock exchange (HOSE) and Ha Noi stock Exchange (HNX). The reasons I choose companies on Ho Chi Minh stock market are: (1) liquidity of HOSE is higher than that of HNX and (2) the financial standards including sales, profit, capital and other criteria for listing on HOSE are stricter than that on HNX. The database is collected from website www.cafef.vn, which include figures of foreign investors' transaction (buying and selling value) and Ho Chi Minh stock exchange index (VN-index). The selected period is from 01/01/2011 to 24/11/2015 and sample size is 1215 trading days

\subsection{Dependent Variables}

The first dependent variable is equity market's performance which is proxied by VN-Index. It represents the trends in the prices of all shares listed and traded on HOSE. The VN-Index compares the current market capitalization value to it on the date of the original base date 28/07/2000- the first day the stock market was officially operated. Market capitalization value is adjusted in the cases listed as new, delisted and changed circumstances listed capital.

VN-Index is calculated as VN Index $=(\mathrm{CMV} / \mathrm{BMV}) \mathrm{x} 100$ where:

$$
\begin{aligned}
& C M V=\sum\left(P_{i, t} \times Q_{i, t}\right) \\
& B M V=\sum\left(P_{i, 0)} \times Q_{i, 0}\right) \\
& C M V: \text { market capitalization value at time } t \\
& B M V: \text { market capitalization value at time } 0 \\
& P_{i, t}: \text { Price of stock I at time } t \\
& Q_{i, t}: \text { Number of outstanding share at time } t \\
& P_{i, 0}: \text { Price of stock I at time } 0 \\
& Q_{i, 0}: \text { Number of outstanding share at time } 0
\end{aligned}
$$

The second explained variable is market liquidity. Sarr \& Lybek (2002) conducted the framework of measuring liquidity of financial market. This study mentions that the trading volume is an important information factor to estimate liquidity of equity market. The market having large trades allows investors diversify their portfolio as well as help the dealers to identify potential customers. Therefore, liquidity of stock market is estimated by trading volume.

\subsection{Independent Variables}

In order to measure the trading activity of foreign sector, net purchase is chosen as its proximity. The details of all variables are descripted in below table:

Table 1. Variables description and measurement

\begin{tabular}{lll}
\hline Variables & Code & How to measure \\
\hline Stock market performance & VNI & Measured by VN-index daily \\
Market liquidity & LIQ & Trading volume of whole market \\
Trading activity of foreign investors & NET & Equals Purchase volume - Selling volume \\
\hline
\end{tabular}




\subsection{Methodology}

First, Pool Ordinary Least Square Regression (OLS) for time series data is used for this paper to exam the relationship between transactions of foreign investors and Vietnamese stock market. It is the same as Choe, Kho, Stulz (2005). Model (1) and model (2) are used to examine the net purchase of foreign sector on market index and liquidity respectively. The original models are constructed as follows:

$$
\begin{aligned}
\text { Model 1:VNI } & =\alpha_{0}+\alpha_{1} N E T+\varepsilon_{t} \\
\text { Model 2:LIQ } & =\alpha_{0}+\alpha_{1} N E T+\varepsilon_{t}
\end{aligned}
$$

\section{Data Analysis and Empirical Results}

\subsection{Data Description}

Table 2 illustrates some descriptions about Ho Chi Minh stock exchange. It can be clearly seen that its scale is small and there are some special points of Vietnamese market. First, VN-index fluctuates in wide range of 336.73-640.75 within 4 years from 2011-2014. It makes standard deviation very big. Second, the proportion of foreign investors over whole market is quite small. This proves that Vietnamese stock market is not attractive enough for foreign investor to inject capital to it.

\begin{tabular}{|c|c|c|c|c|c|}
\hline & Number of observation & Mean & Standard deviation & Min & Max \\
\hline VN-index & 1215 & 497.57 & 76.22 & 336.73 & 640.75 \\
\hline Total trading volume (millions of stock) & 1215 & 77.50 & 45.60 & 14.90 & 279 \\
\hline Purchase volume (millions of stock) & 1215 & 6.10 & 5.90 & 0.54 & 78.70 \\
\hline $\begin{array}{l}\text { Percentage of purchase volume of foreign } \\
\text { investor over whole market (\%) }\end{array}$ & 1215 & 8.60 & 5.36 & 1.28 & 74 \\
\hline $\begin{array}{l}\text { Selling volume } \\
\text { (millions of stock) }\end{array}$ & 1215 & 5.60 & 6.40 & 0.40 & 106 \\
\hline $\begin{array}{l}\text { Percentage of selling volume of foreign investor } \\
\text { over whole market (\%) }\end{array}$ & 1215 & 7.90 & 5.99 & 5.53 & 77 \\
\hline $\begin{array}{l}\text { Net purchase } \\
\text { (millions of stock) }\end{array}$ & 1215 & 0.51 & 5.23 & -10.42 & 51.11 \\
\hline
\end{tabular}

Table 2. Some description about Ho Chi Minh stock market

Graph 3 presents relationship between VN-index, market liquidity and net purchase of foreign sector. Generally, $\mathrm{VN}$-index is associated positively by the purchase of foreign investors. During the period time net purchase is positive, VN-index usually increases. For the relationship between total transaction of market and trading activity of foreign investors, it seems that there is no relationship between them. However, liquidity of stock market normally reduces after tremendous rise. In addition, it can be clearly seen that the VN-Index is non-stationary.

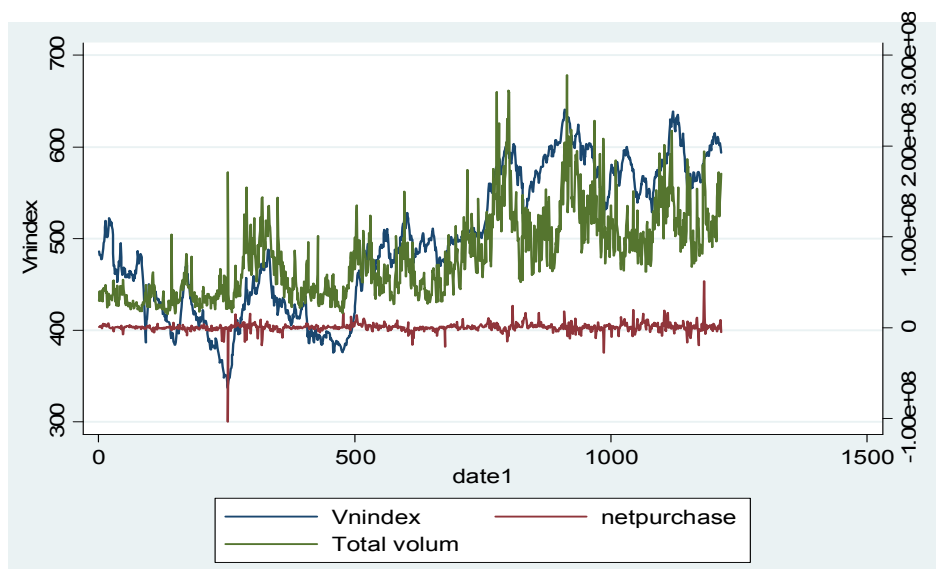

Graph 3. Relationship between VN-index, total transaction volume of stock market and Net purchase of foreign investor 


\subsection{Regression and Discussion}

\subsubsection{Regression Analyses and Results}

Table 3 shows the regression and test results for heteroskedasticity and serial correlation-two most moderate problems in OLS regression. As can be seen, panel A indicates there is no heteroskedasticity in model (1) while model (2) contains heteroskedastic problem. For autocorrelation, it happens in both models.

Table 3. Test of heteroskedasticity and autocorrelation

\begin{tabular}{|c|c|c|}
\hline \multicolumn{3}{|c|}{ Panel A: Breusch-Pagan / Cook-Weisberg test for heteroskedasticity } \\
\hline & Model 1 & Model 2 \\
\hline Chi-square & 1.43 & 48.63 \\
\hline Prob.> Chi-square & 0.23 & 0.00 \\
\hline \multicolumn{3}{|c|}{ Panel B: Breusch-Godfrey LM test for autocorrelation } \\
\hline & Model 1 & Model 2 \\
\hline Chi-square & 1197.47 & 768.72 \\
\hline Prob.> Chi-square & 0.00 & 0.00 \\
\hline
\end{tabular}

For model (1), as graph 3 shows, $\mathrm{VN}$-index is non-stationary. The first difference of $\mathrm{VN}$-index which is coded as FDVNI is used to solve this problem. Dickey Fuller test will be used to test whether three variables are stationary. Table 4 presents p-value equals zero, which means the null hypothesis of unit root with drift is rejected. All variables become stationary.

Table 4. Dickey fuller test of unit root: $Z(t)$ value

\begin{tabular}{lllll}
\hline & Test statistic & $\mathbf{1 \%}$ critical value & $\mathbf{5 \%}$ critical value & $\mathbf{1 0 \%}$ critical value \\
\hline FDVNI & -30.87 & -3.43 & -2.86 & -2.57 \\
LQI & -9.54 & -3.43 & -2.86 & -2.57 \\
NET & -26.87 & -3.43 & -2.86 & -2.57 \\
\hline P-value for $Z(\mathrm{t})=0.00$ & & & \\
\hline
\end{tabular}

Besides, because this is time series data and dependent variables can be influenced its lagged variables, Vector Autoregressive model is used to find out maximum lag order. As a result, the maximum lag orders are second and fifth for FDVNI and LQI respectively. Finally, for fixing the autocorrelation and heteroskedasticity problems, ARCH model is run. Two final models to examine to impact of foreign transactions on Vietnamese stock market are revised as follows:

$$
\begin{gathered}
\text { Model 3: } F D V N I_{t}=\alpha_{0}+\alpha_{1} N E T_{t}+\alpha_{2} F D V N I_{t-1}+\alpha_{3} F D V N I_{t-2}+\varepsilon_{t} \\
\text { Model 4: } L Q I_{t}=\alpha_{0}+\alpha_{1} N E T_{t}+\alpha_{2} L Q I_{t-1}+\alpha_{3} L Q I_{t-2}+\alpha_{4} L Q I_{t-3}+\alpha_{5} L Q I_{t-4}+\alpha_{6} L Q I_{t-5}+\varepsilon_{t}
\end{gathered}
$$

Table 5. Results by using ARCH regression for model (3)

\begin{tabular}{ll}
\hline & FDVNI \\
\hline NET & $6.83 \mathbf{e}^{-8 *}$ \\
FDVNI $t-1$ & $0.10^{*}$ \\
FDVNI $_{t-2}$ & $0.05^{*}$ \\
\hline
\end{tabular}

Note. $*$ denote significant level at $1 \%$.

Table 6. Results by using ARCH regression for model (4)

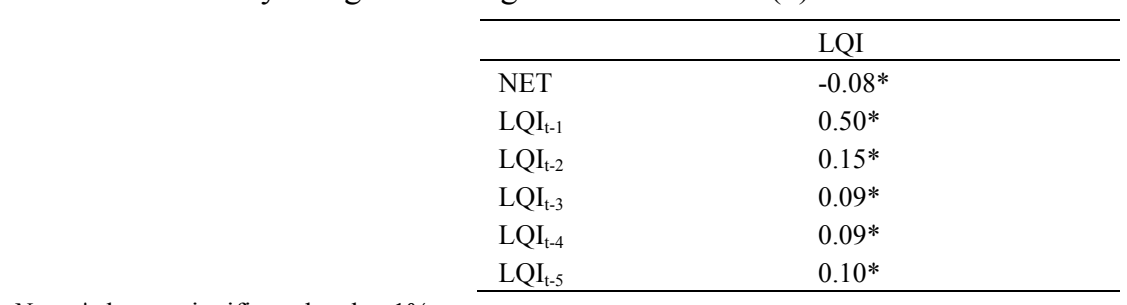

Note. $*$ denote significant level at $1 \%$. 


\subsubsection{Discussion and Explanation}

As result of table 5, 1 unit of net purchase makes $\mathrm{VN}$-index increase $6.83 e^{-8}$. This is strong evidence about positive relationship between net purchase of foreigners and VN-index, which is similar with Richard (2005) and Griffin, Nardari, \& Stulz (2003). These papers suggest that net cash inflow of foreign investors cause momentum effect to market price and increase equity index. Moreover, Ciner \& Karagozoglu (2007) confirm that asymmetric information is the main problem in emerging market and the participation of foreigners will reduce this phenomenon. In other hand, foreign investors are usually professional institutes and have strong capital, so their trading activities tend to become the pattern for domestic investors, especially individual investor. Other interesting finding of this paper is that market performance of day $t$ is associated positively by market performance of day t-1 and day t-2. It means that $\mathrm{VN}$-index usually moves continuously at the same trend in three days by the effect of lag factor. As appropriate explanation, in Vietnamese stock market, the government regulates that waiting time for receiving stocks after buying them is $t+3$. If investors buy stocks at day $t$, they will receive and trade them at day $t+3$. However, the impact of lag factor becomes weaker for day $t-2$ compared with day $\mathrm{t}-1$.

The main second finding of this research is to give strong evidence to prove that net purchase of foreign investors affects negatively on market liquidity. As regressive result, 1 unit of net purchase volume reduces 0.075 unit of total trading volume. This is the same as result of Samal (1997). In reality, this phenomenon that net purchase of foreign sector leads positive influence on $\mathrm{VN}$-index but causes opposite one to market liquidity is normal. It can be interpreted that in Vietnamese equity market, foreign investors prefer trading the stocks of firm with high market capitalization rather than mid-cap and small-cap shares. These companies usually have good financial performance, transparence in public information and clear disclosure. This is proved completely by Aggarwal, Klapper, \& Wysocky (2005). As a result, it leads to the increase in VN-index but reduction in liquidity. This empirical resultdoes not support the conclusions of Dahlquist \& Robertsson (2004) and Merton (1987) trading activity of foreign investor increases market liquidity. Rhee \& Wang (2009) also point out that there are some mechanisms to explain that the participation of large foreign corporation in small markets does not enhance market liquidity. Their transactions cause some issues for stock markets: (1) higher volatility; (2) greater asymmetric information; (3) inactive trading - buy and hold strategy; (4) dominant traders. In Vietnamese market, buy and hold strategy is appropriate explanation for adverse impact of foreign investors' trading on market liquidity.

\section{Conclusion}

This research concludes the positive relationship between trading activity of foreign investors and performance of equity market. However, it also points out that the market liquidity reduces on the days foreign investors take net purchase. In addition, stock market index is influenced by lag factor, which match with Vietnamese regulation and features. This study gives appropriate evidence to prove that foreign investors tend to trade high market capitalization stocks, which have significant impact on market growth. In reality, in Vietnam, ownership of foreign sector over Vietnamese companies is still restricted. It could be the reason why although there is participation of foreign investors, liquidity does not go up. Besides, as Ciner \& Karagozoglu (2007), asymmetric information and regulation system are big issues for emerging market. The empirical finding challenges the view that financial liberalization brings a lot of advantages to equity market like reducing cost of capital and risk as well as improving market liquidity for emerging countries.

\section{References}

Aggarwal, R., Klapper, L., \& Wysocki, P. D. (2005). Portfolio preferences of foreign institutional investors. Journal of Banking \& Finance, 29(12), 2919-2946. http://dx.doi.org/10.1016/j.jbankfin.2004.09.008

Bae, K. H., Ozoguz, A., Tan, H., \& Wirjanto, T. S. (2012). Do foreigners facilitate information transmission in emerging markets? Journal of Financial Economics, 105(1), 209-227. http://dx.doi.org/10.1016/j.jfineco.2012.01.001

Bekaert, G., \& Harvey, C. R. (1997). Emerging equity market volatility. Journal of Financial Economics, 43(1), 29-77. http://dx.doi.org/10.1016/S0304-405X(96)00889-6

Bekaert, G., \& Harvey, C. R. (2000). Foreign speculators and emerging equity markets. The Journal of Finance, 55(2), 565-613. http://dx.doi.org/10.1111/0022-1082.00220

Bekaert, G., Harvey, C. R., \& Lundblad, C. T. (2003). Equity market liberalization in emerging markets. Journal of Financial Research, 26(3), 275-299. http://dx.doi.org/10.1111/1475-6803.00059

Bley, J., \& Saad, M. (2011). The effect of financial liberalization on stock-return volatility in GCC markets. 
Journal of International Financial Markets, Institutions and Money, 21(5), 662-685. http://dx.doi.org/10.1016/j.intfin.2011.04.003

Cajueiro, D. O., Gogas, P., \& Tabak, B. M. (2009). Does financial market liberalization increase the degree of market efficiency? The case of the Athens stock exchange. International Review of Financial Analysis, 18(1), 50-57. http://dx.doi.org/10.1016/j.irfa.2008.11.004

Chan, K., Menkveld, A. J., \& Yang, Z. (2007). The informativeness of domestic and foreign investors' stock trades Evidence from the perfectly segmented Chinese market. Journal of Financial Markets, 10(4), 391-415. http://dx.doi.org/10.1016/j.finmar.2007.07.001

Choe, H., Kho, B. C., \& Stulz, R. M. (1999). Do foreign investors destabilize stock markets The Korean experience in 1997. Journal of Financial Economics, 54(2), $227-264$. http://dx.doi.org/10.1016/S0304-405X(99)00037-9

Choe, H., Kho, B. C., \& Stulz, R. M. (2005). Do domestic investors have an edge: The trading experience of foreign investors in Korea. Review of Financial Studies, 18(3), $795-829$. http://dx.doi.org/10.1093/rfs/hhi028

Ciner, C., \& Karagozoglu, A. K. (2008). Information asymmetry, speculation and foreign trading activity: Emerging market evidence. International Review of Financial Analysis, 17(4), 664-680. http://dx.doi.org/10.1016/j.irfa.2007.09.003

Edison, H. J., Klein, M. W., Ricci, L. A., \& Sløk, T. (2004). Capital account liberalization and economic performance: Survey and synthesis. IMF Staff Papers, 51(2), 220-256. http://dx.doi.org/10.2307/30035874

Edison, H. J., Levine, R., Ricci, L., \& Sløk, T. (2002). International financial integration and economic growth. Journal of International Money and Finance, 21(6), 749-776. http://dx.doi.org/10.1016/S0261-5606(02)00021-9

Griffin, J. M., Nardari, F., \& Stulz, R. M. (2004). Are daily cross-border equity flows pushed or pulled? Review of Economics and Statistics, 86(3), 641-657. http://dx.doi.org/10.1162/0034653041811725

Hamao, Y., \& Mei, J. (2001). Living with the "enemy" an analysis of foreign investment in the Japanese equity market. Journal of International Money and Finance, 20(5), 715-735. http://dx.doi.org/10.1016/S0261-5606(01)00006-7

Han Kim, E., \& Singal, V. (2000). Stock Market Openings Experience of Emerging Economies. The Journal of Business, 73(1), 25-66. http://dx.doi.org/10.1086/209631

Henry, P. B. (2000). Do stock market liberalizations cause investment booms? Journal of Financial Economics, 58(1), 301-334. http://dx.doi.org/10.1016/S0304-405X(00)00073-8

Henry, P. B. (2000). Stock market liberalization, economic reform, and emerging market equity prices. The Journal of Finance, 55(2), 529-564. http://dx.doi.org/10.1111/0022-1082.00219

Kaminsky, G., \& Schmukler, S. (2003). Short-run pain, long-run gain: the effects of financial liberalization (No. w9787). National Bureau of Economic Research. http://dx.doi.org/10.1093/rof/rfn002

Kassimatis, K. (2002). Financial liberalization and stock market volatility in selected developing countries. Applied Financial Economics, 12(6), 389-394. http://dx.doi.org/10.1080/09603100010001937

Kawakatsu, H., \& Morey, M. R. (1999). An empirical examination of financial liberalization and the efficiency of emerging market stock prices. Journal of Financial Research, 22(4), 385-411. http://dx.doi.org/10.1111/0022-1082.00219

Klein, M., \& Olivei, G. (1999). Capital Account Liberalization, Financial Depth and Economic Growth. NBER Working Paper\# 7384. I. http://dx.doi.org/10.1016/j.jimonfin.2008.05.002

Kraay, A. (1998). In search of the macroeconomic effects of capital account liberalization. ResearchGate.

Levine, R., \& Zervos, S. (1998). Capital control liberalization and stock market development. World Development, 26(7), 1169-1183. http://dx.doi.org/10.1596/1813-9450-1622

Merton, R. C. (1987). A simple model of capital market equilibrium with incomplete information. The Journal of Finance, 42(3), 483-510. http://dx.doi.org/10.1111/j.1540-6261.1987.tb04565.x

Mitton, T. (2006). Stock market liberalization and operating performance at the firm level. Journal of Financial Economics, 81(3), 625-647. http://dx.doi.org/10.1016/j.jfineco.2005.09.001 
Mukherjee, P., Bose, S., \& Coondoo, D. (2002). Foreign institutional investment in the Indian equity market: An analysis of daily flows during January 1999-May. Money \& Finance, 2(9-10). http://dx.doi.org/10.2139/ssrn.430700

Quinn, D. (1997). The correlates of change in international financial regulation. American Political Science Review, 91(3), 531-551. http://dx.doi.org/10.2307/2952073

Rhee, S. G., \& Wang, J. (2009). Foreign institutional ownership and stock market liquidity Evidence from Indonesia. Journal of Banking \& $\quad$ Finance, $\quad 33(7), \quad 1312-1324$. http://dx.doi.org/10.1016/j.jbankfin.2009.01.008

Richards, A. (2005). Big fish in small ponds: The trading behavior and price impact of foreign investors in Asian emerging equity markets. Journal of Financial and Quantitative Analysis, 40(1), 1-27. https://doi.org/10.1017/S0022109000001721

Rodrik, D. (1998). Who needs capital-account convertibility? Essays in International Finance, 55-65.

Samal, K. C. (1997). Emerging equity market in India: role of foreign institutional investors. Economic and Political Weekly, 2729-2732.

Sarr, A., \& Lybek, T. (2002). Measuring liquidity in financial markets. Social Science Electronic Publishing, 2(2), 232.

Stulz, R. M. (1999). Globalization, corporate finance, and the cost of capital. Journal of Applied Corporate Finance, 12(3), 8-25. http://dx.doi.org/10.1111/j.1745-6622.1999.tb00027.x

Umutlu, M., Akdeniz, L., \& Altay-Salih, A. (2010). The degree of financial liberalization and aggregated stock-return volatility in emerging markets. Journal of Banking \& Finance, 34(3), 509-521. http://dx.doi.org/10.1016/j.jbankfin.2009.08.010

Wang, J. (2007). Foreign equity trading and emerging market volatility Evidence from Indonesia and Thailand. Journal of Development Economics, 84(2), 798-811. http://dx.doi.org/10.1016/j.jdeveco.2006.05.001

\section{Copyrights}

Copyright for this article is retained by the author, with first publication rights granted to the journal.

This is an open-access article distributed under the terms and conditions of the Creative Commons Attribution license (http://creativecommons.org/licenses/by/4.0/). 